\title{
Urban Early Childhood Educators’ Perceptions of the Impact of NCLBon Their Literacy Practices
}

\author{
Terry Husband ${ }^{1, *}$ \\ ${ }^{1}$ Illinois State Univeristy, Normal, Illinois, USA \\ *Correspondence: Illinois State University, Campus Box 5330, Normal, IL, 61790, USA. Tel: 1-438-8401 E-mail: \\ thusban@ilstu.edu
}

Received: December 13, 2013

Accepted: January 26, 2014 Online Published: February 11, 2014

doi:10.5430/jct.v3n1p47

URL: http://dx.doi.org/10.5430/jct.v3n1p47

\begin{abstract}
While much has been written concerning the impact of NCLB on students, teachers, parents, administrators, and policies makers in general, little has been documented about the impact of NCLB on urban early childhood educators' literacy practices in particular. The purpose of this paper is to present the preliminary findings from a research study that examines urban early childhood educators' perceptions of NCLB on their literacy practices. An on-line survey was administered to 47 urban early childhood educators in grades P-3 in an urban school district in the Midwest part of the United States of America. While a significant percentage of the teachers surveyed perceive that NCLB has had a largely negative impact on curriculum, literacy instruction and student achievement overall, it has, nonetheless, led to a more rigorous curriculum in their classrooms.
\end{abstract}

Keywords: NCLB, urban educators, early childhood

\section{Introduction}

\subsection{Introduction}

Arguably, The No Child Left Behind (NCLB) act is the most significant educational policy ever enacted by the United States federal government. Since it was signed into law in 2002, a preponderance of scholarship has been written related to its impact among schools in general and students, teachers, parents, administrators, and policy makers in particular (e.g., Abernathy, 2007; Cawelti, 2006; Essex, 2006; Fletcher, 2006 Gensler, 2006; Karp, 2004; Meijer \& Wood, 2004; Popham, 2004; Sunderman, James \& Orfield 2005). NCLB evaluates a school's effectiveness based on its progress toward meeting adequate yearly progress (AYP) goals for student achievement on state established assessment measures. As a result, much of the scholarship on NCLB has examined its impact on teachers and students in grades 3 and beyond, where students in most states begin taking the standardized measures linked to AYP scores. Few studies examine the impact of NCLB on early childhood teachers in grades P-3. To this end, an even smaller number of studies examine how NCLB impacts the literacy practices of urban early childhood educators in particular. Given the fact that large numbers of urban schools have significant numbers of students who are not performing at proficient levels in reading, it is plausible that NCLB has had an impact on urban early childhood educators that warrants examination.

The purpose of this study is to examine urban early childhood educators' perceptions of NCLB on their literacy practices. The overarching research question that drives this study is: What are urban early childhood educators' perceptions of the impact of NCLB on their literacy practices? Other questions include:

1. What are urban early childhood educators' perceptions of the impact of NCLB on the literacy curriculum in their classrooms?

2. What are urban early childhood educators' perceptions of the impact of NCLB on the literacy instruction in their classrooms? 
3. What are urban early childhood educators' perceptions of the impact of NCLB on student achievement in their classrooms?

\subsection{Significance}

This study is significant because it provides insight into how NCLB is impacting teachers in early childhood contexts. To date, the majority of scholarship into NCLB centers on teachers in grade 3 and beyond. Relatively little has been documented related to how NCLB impacts teachers in earlier grades. Findings from this study contribute to this gap within the scholarship. Moreover, given the recent 10 year anniversary of the NCLB legislature, it is important to begin to examine how NCLB impacts specific groups of teachers in specific contexts within the K-12 educational continuum as a means of making recommendations for future revisions to this law.

\subsection{Relevant Scholarship}

This study draws from three streams of scholarship within the NCLB literature. First, this study draws from perspectives related to NCLB and its impact on teachers' curriculum and pedagogical experiences broadly (e.g., Abernathy, 2007; Cawelti, 2006; Essex, 2006; Fletcher, 2006 Gensler, 2006; Karp, 2004; Meijer \& Wood, 2004; Popham, 2004; Sunderman, James \& Orfield 2005). Essentially, these perspectives argue that NCLB applies a universal approach to school reform that fails to account for the diversity and complexities embedded in varying classroom contexts. As a result, it (NCLB) has a negative consequence on teachers' pedagogical practices. For example, Cawelti (2006) argues that NCLB demoralizes teachers, diverts attention from non-tested subjects, and pressures teachers to manipulate testing data to meet their needs. The present study builds on and extends this body of scholarship as it examines the impact of NCLB on urban early childhood educators' instructional experiences.

In addition, this study draws from critical perspectives on NCLB and its impact on urban teachers in particular (e.g., Crocco \& Costigan, 2007; Karp, 2004; Sadovnik, O’Day, Bohrnstedt \& Borman, 2007; Shealey, 2006; Wood, 2004). These perspectives suggest that urban teachers are more adversely impacted by NCLB than teachers in other contexts-due primarily to the large numbers of below "proficient" students who typically comprise urban classrooms. For example, in a survey administered to teachers in 49 predominantly low-income and minority schools in Richmond, Virginia, Sunderman, Tracey, Kim and Orfield (2004) found that disproportionate numbers of teachers (over 50\%) de-emphasized or neglected untested topics in the curriculum due to the adequate yearly progress (AYP) requirements in NCLB. In keeping with these perspectives, the present study seeks to examine the relationship between NCLB and the literacy practices of urban early childhood educators.

Finally, this study draws from critical perspectives on NCLB and its negative impact on early childhood teachers' curriculum and pedagogical experiences (e.g., Eunsook, 2003; Gammage, 2006; Fuller, 2007; Goldstein, 2008; Stipeck, 2006). In short, these perspectives highlight two recurrent consequences of NCLB on early childhood teaching practices. First, in an effort to better prepare students for NCLB based standardized testing at the end of the primary grades, large numbers of early childhood educators report being forced to teach curriculum that was traditionally withheld until later grades. Moreover, these perspectives assert that NCLB pressures early childhood teachers to teach in ways that are considered to be "developmentally inapproriate". For example, Cooper (2005) points out that storytelling and drama based reading programs are being replaced with skills-based reading programs to fulfill the requirements of NCLB in many early childhood classrooms. Further, the present study draws from this body of research, as it examines the impact of NCLB on early childhood educators' literacy practices.

\section{Method}

\subsection{Setting}

Data for this study was collected by administering an on-line survey to urban early childhood educators in grades P-3 in one large urban school district in the Midwest part of the United States of America. Based on most recent enrollment data, the school district has approximately 9,179 students. The racial/ethnic student demographics are as follows:

(a) $42.2 \%$ of the students are White

(b) $35.6 \%$ of the students are Black

(c) $8.0 \%$ of the students are Hispanic

(d) $9.4 \%$ of the students are Asian 
(e) $0.1 \%$ of the students are Native Hawaiian

(f) $0.4 \%$ of the students are American Indian

(g) $4.3 \%$ of the students are Biracial

Moreover, $52.8 \%$ of the students qualify for free or reduced lunch. Approximately $13.8 \%$ of the students in the district have an Individual Education Plan (IEP) on file and or are eligible to receive special education services. Finally, 5.5\% of the students are eligible for transitional bilingual programs.

\subsection{Participants/Sampling}

Participants $(\mathrm{n}=205)$ were invited to participate in the study based on convenience sampling (Fink, 1995) criteria: The following criteria were used to solicit participation in the study:

1) Teachers with three or more years of teaching experience in that district or another urban school district

2) Teach in grades $P-3$

3) Teachers who are responsible for teaching reading and writing on a consistent basis

Based on the convenience sampling criteria, 205 teachers were invited to participate in the study through a formal letter sent via email. A total of 47 out 205 teachers in grades P-3 responded to the survey invitation. This number represents a response rate of $23 \%$. The largest percentage of respondents identified themselves exclusively as first grade teachers (Figure 1). Approximately 21\% $(\mathrm{n}=10)$ of the respondents identified themselves exclusively as preschool teachers. Approximately 21\% $(\mathrm{n}=10)$ of the respondents identified themselves exclusively as kindergarten teachers. Approximately 23\% $(\mathrm{n}=11)$ of the respondents identified themselves exclusively as first grade teachers. Approximately $9 \%(n=4)$ of the respondents identified themselves exclusively as second grade teachers. Approximately 15\% ( $\mathrm{n}=7)$ of the respondents identified themselves exclusively as third grade teachers. Approximately 11\% $(n=5)$ of the respondents indentified themselves as teachers of multiple grades P-3 (Figure 1).

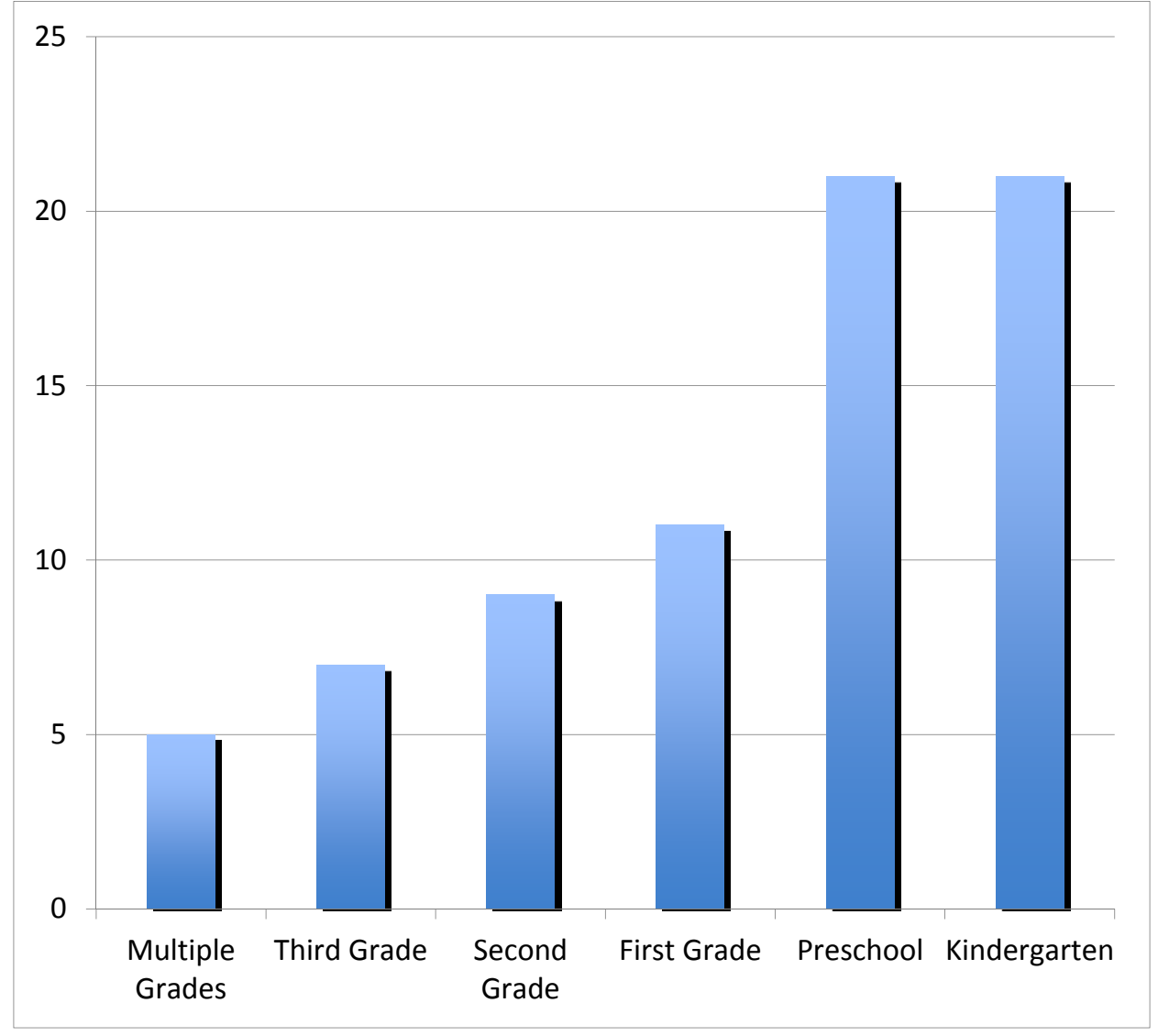

Figure 1. Percentage of Respondents at Each Grade Level 


\subsection{Instrument}

An electronic survey was constructed by the researcher and used to examine urban early childhood educators' perceptions of the impact of NCLB on their literacy practices. The researcher constructed the survey based on two previously conducted surveys (Sunderman, Kim, \& Orfield, 2004; IRA, 2005) in the NCLB literature. The survey consists of a Likert Scale with 15 statements for respondents to check the degree to which they agree/disagree with the statements presented. Two of the items on the survey pose questions related to how long the teachers have been teaching and the grade level they currently teach.

\section{Results}

\subsection{Data Analysis}

The researcher used a descriptive statistical technique to calculate the frequencies, means and standard deviations of the collected data. Data was analyzed in relation to the three sections of items presented on the survey: impact on curriculum, impact on literacy instruction, and impact on student achievement.

\subsection{Impact on Curriculum}

The descriptive results for the 15 items appearing on the survey, including the percentages of response for each point on the scale, means, and standard deviations are presented in Table 1. With respect to the teachers' perceptions of the impact of NCLB on the literacy curriculum, nearly $49 \%$ of the teachers agree that NCLB has narrowed the literacy in their classrooms. Nearly $47 \%$ of the teachers agree that NCLB has led to a more rigorous literacy curriculum in their classrooms. Only $21 \%$ of the teachers agree that NCLB has expanded the literacy curriculum in their classrooms. Conversely, $49 \%$ of the teachers disagreed that NCLB has expanded the literacy curriculum in their classrooms. Only $28 \%$ of the teachers agreed that NCLB has had an overall positive impact on the literacy curriculum in their classroom. On the other hand, 38\% of the teachers disagreed that NCLB has had an overall positive impact on the literacy curriculum in their classrooms.

\subsection{Impact on Literacy Instruction}

With respect to teachers' perceptions of the impact of NCLB on their literacy instructional practices, only $17 \%$ of the teachers agreed that NCLB has led to higher levels of literacy instruction in their classrooms. Conversely, approximately $45 \%$ of the teachers disagreed that NCLB has led to higher levels of literacy instruction in their classrooms. Nearly 34\% of the teachers agreed that NCLB has lead to increased instances of differentiated literacy instruction in their classrooms. Approximately $32 \%$ of the teachers agreed that NCLB has lead to increased instances of small-group literacy instruction in their classrooms. Concerning whole-group instruction, only $10 \%$ of the teachers agreed that NCLB has increased instances of whole-group literacy instruction in their classrooms. Conversely, approximately $47 \%$ of the teachers disagreed that NCLB has increased instances of whole-group literacy instruction in their classrooms. Only $14 \%$ of the teachers agreed that NCLB has had a positive impact on literacy instruction in their classrooms overall.

\subsection{Impact on Student Achievement}

With respect to teachers' perceptions of the impact of NCLB on student achievement, only $17 \%$ of the teachers agreed that NCLB has lead to increases in student achievement in reading and writing in their classrooms. Nearly $41 \%$ of the teachers disagreed that NCLB has lead to increases in student achievement in reading and writing in their classrooms. Only $6 \%$ of the teachers agreed that NCLB has decreased the achievement gap in reading and writing between minority and non-minority students in their classrooms. Approximately $51 \%$ of the teachers disagreed that NCLB has decreased the achievement gap in reading and writing between minority and non-minority students in their classrooms. Only 19\% of the teachers agreed that NCLB has increased reading and writing achievement among low achieving student groups in their classrooms. Specifically concerning high achieving students, only $15 \%$ of the teachers agreed that NCLB has increased student achievement among high achieving students in their classrooms. Conversely, approximately $40 \%$ of the teachers disagreed that NCLB has increased student achievement among high achieving students in their classrooms. Finally, only $13 \%$ of the teachers agreed that NCLB has had a positive impact on student achievement in their classroom overall. Interestingly, $49 \%$ of the teachers disagreed that NCLB has had a positive impact on student achievement in their classroom overall (Table 1). 
Table 1. Overall Description of Survey Results

\begin{tabular}{|c|c|c|c|c|c|c|c|}
\hline & $\begin{array}{l}\text { SD } \\
\%\end{array}$ & $\begin{array}{l}\mathrm{D} \\
\%\end{array}$ & $\begin{array}{l}\mathrm{N} \\
\% \\
\end{array}$ & $\begin{array}{l}\text { A } \\
\%\end{array}$ & $\begin{array}{l}\text { SA } \\
\%\end{array}$ & Mean & $\begin{array}{l}\text { Standard } \\
\text { Deviation }\end{array}$ \\
\hline $\begin{array}{l}\text { No Child Left Behind has narrowed the literacy } \\
\text { curriculum in my classroom }\end{array}$ & 2 & 13 & 36 & 28 & 21 & 3.532 & 1.039 \\
\hline $\begin{array}{l}\text { No Child Left Behind has led to a more rigorous } \\
\text { literacy curriculum in my classroom }\end{array}$ & 11 & 23 & 19 & 26 & 21 & 3.234 & 1.322 \\
\hline $\begin{array}{l}\text { No Child Left Behind has expanded the literacy } \\
\text { curriculum in my classroom }\end{array}$ & 11 & 38 & 30 & 15 & 6 & 2.681 & 1.065 \\
\hline $\begin{array}{l}\text { No Child Left Behind has led to a more relevant } \\
\text { literacy curriculum in my classroom }\end{array}$ & 15 & 32 & 34 & 15 & 4 & 2.617 & 1.054 \\
\hline $\begin{array}{l}\text { Overall, No Child Left Behind has had a positive } \\
\text { impact on the literacy curriculum in my classroom }\end{array}$ & 21 & 17 & 34 & 28 & 0 & 2.681 & 0.319 \\
\hline $\begin{array}{l}\text { No Child Left Behind has led to higher levels of } \\
\text { literacy instruction in my classroom }\end{array}$ & 15 & 30 & 38 & 15 & 2 & 2.596 & 0.993 \\
\hline $\begin{array}{l}\text { No Child Left Behind has led to increased instances } \\
\text { of differentiated literacy instruction in my classroom }\end{array}$ & 8 & 26 & 32 & 30 & 4 & 2.957 & 1.042 \\
\hline $\begin{array}{l}\text { No Child Left Behind has lead to increased instances } \\
\text { of small-group literacy instruction in my classroom }\end{array}$ & 2 & 19 & 47 & 23 & 9 & 3.170 & 0.916 \\
\hline $\begin{array}{l}\text { No Child Left Behind has increased instances of } \\
\text { whole-group literacy instruction in my classroom }\end{array}$ & 9 & 38 & 43 & 6 & 4 & 2.596 & 0.901 \\
\hline $\begin{array}{l}\text { Overall, No Child Left Behind has had a positive } \\
\text { impact on literacy instruction in my classroom }\end{array}$ & 15 & 26 & 45 & 12 & 2 & 2.617 & 0.968 \\
\hline $\begin{array}{l}\text { No Child Left Behind has lead to increases in student } \\
\text { achievement in reading and writing in my classroom }\end{array}$ & 15 & 26 & 42 & 17 & 0 & 2.617 & 0.945 \\
\hline $\begin{array}{l}\text { No Child Left Behind has decreased the achievement } \\
\text { gap in reading and writing between minority and } \\
\text { non-minority students in my classroom }\end{array}$ & 21 & 30 & 43 & 4 & 2 & 2.362 & 0.942 \\
\hline $\begin{array}{l}\text { No Child Left Behind has increased reading and } \\
\text { writing achievement among low achieving student } \\
\text { groups in my classroom. }\end{array}$ & 8 & 28 & 45 & 11 & 8 & 2.830 & 1.028 \\
\hline $\begin{array}{l}\text { No Child Left Behind has increased student } \\
\text { achievement among high achieving students in my } \\
\text { classroom }\end{array}$ & 14 & 26 & 45 & 13 & 2 & 2.617 & 0.968 \\
\hline $\begin{array}{l}\text { Overall, No Child Left Behind has had a positive } \\
\text { impact on student achievement in my classroom }\end{array}$ & 19 & 30 & 38 & 13 & 0 & 2.447 & 0.951 \\
\hline
\end{tabular}

$\mathrm{SD}=$ Strongly Disagree $\quad \mathrm{D}=$ Disagree $\quad \mathrm{N}=$ No Opinion $\quad \mathrm{A}=$ Agree

$\mathrm{SA}=$ Strongly Agree 


\section{Discussion}

Much like the extant literature on NCLB and its impact on teachers in general, the urban early childhood teachers in this study perceived that NCLB has had a largely negative impact on the curriculum, instruction and student achievement (with respect to literacy) in their classrooms. Nonetheless, there are three important findings from this study that warrant further discussion. First, nearly $49 \%$ of the teachers who participated in the study agreed that NCLB has narrowed the literacy curriculum in their classroom. This suggests that early childhood teachers in grades P-3 are being impacted by NCLB in much of the same ways as teachers who teach in grades 4 and beyond. Although teachers in grades P-3 typically do not give assessments that are directly associated with a school's AYP score, they are still being impacted by the mandates of NCLB in their literacy classrooms. One possible explanation for this impact, according to Eunsook (2003), is that NCLB forces administrators to place pressure on early childhood teachers in grades P-3 to to introduce tested content earlier as a means of increasing testing outcomes.

Next, nearly half (47\%) of the teachers perceived that NCLB has led to a more rigorous literacy curriculum in their classroom. This finding directly contrasts much of the previous scholarship on NCLB that suggests that NCLB actually places an overemphasis on student mastery of lower level basic skills. What is unclear relative to this particular finding is how teachers define and perceive the notion of rigor as it relates to NCLB and their literacy practices. Perhaps, teachers are defining the notion of rigor as being commensurate with structure or formality. It is difficult to conclude based on the data from this study exactly how teachers define this notion or rigor and how this definition relates to their perceptions of NCLB. Follow-up qualitative interviews with these teachers might provide insight into how rigor is being defined and used in their classrooms as it relates to NCLB.

Third, a relatively small percentage of teachers in this study (10\%) attributed NCLB to an increase in whole-group instruction. This finding differs drastically from previous scholarship in this area that suggests that NCLB forces teachers to implement whole-group instructional strategies more often than not. Data from this study suggest that NCLB has more impact over the content early childhood teachers teach than over the manner they choose to teach this content.

The present study was quantitative in nature. As such, little is known about early childhood teachers' daily instructional experiences while adhering to the mandates of NCLB. I recommend three subsequent studies in three areas to add more insight into the findings presented in this study. First, future case studies into this topic might examine the daily experiences of urban early childhood educators who believe that NCLB has lead to more rigorous curriculum opportuniites in their classrooms. Findings from these studies will provide valuable insight into the positive aspects of NCLB, which is largely absent from the present scholarship on this topic.

A second line of future research on this topic might examine the impact of NCLB on urban early childhood educators' literacy practices over an extended period of time. The findings from this study reveal teachers' perceptions at one moment in time. Little is known about how these perceptions change or remain consistent over an extended period of time. Hence, subsequent longitudinal research into this topic might compare how urban early childhood educators' perceptions remain consistent or change from year to year.

A third line of future research on this topic might consist of focus group interviews with urban early childhood educators. While the present study provided clear and concise data related to urban early childhood educators' perceptions of NCLB, little is know about how urban early childhood teachers make sense of the impact of NCLB on their literacy practices in qualitative terms. Hence, subsequent focus group interviews with urban early childhood educators will provide opportunities for teachers to discuss their experiences with NCLB in greater detail and depth.

One potential limitation of the present study is the sample size. Two hundred and five urban early childhood educators were solicited for participation in the study. I received a response rate of $23 \%$, which represents a relatively small sample size. Future studies on this topic might solicit a larger sample size in order to increase the generalizability of the study.

A second potential limitation of the present study is the fact that the survey involved teachers in only one school district. Hence the findings from this study can only be generalized to other urban school districts and schools with similar student demographics. Future studies on this topic might involve multiple urban school districts with varying student demographics to increase the potential for generalizability. 


\section{References}

Abernathy, S. F. (2007). No child left behind and the public schools: Why nclb will fail to close the achievement gap and what we can do about it. Michigan: The University of Michigan Press.

Cawelti, G. (2006). The side effects of nclb. Educational Leadership, 64(3), 64-68.

Crocco, M. S., \& Costigan, A. T. (2007). The narrowing of curriculum and pedagogy in the ageof accountability: Urban educators speak out. Urban Education, 42(6), 512-535. http://dx.doi.org/10.1177/0042085907304964

Essex, N. L. (2006). What every teacher should know about no child left behind. Boston: Allyn and Bacon.

Eunsook, H. (2003). What does the no child left behind act mean to early childhood teachereducators?: A call for collective professional rejoinder. Early Childhood Education Journal, 31(2), 119-124. http://dx.doi.org/10.1023/B:ECEJ.0000005311.05637.c4

Fink, A. (2003). The survey kit: how to sample in surveys. Thousand Oaks, CA: Sage.

Fletcher, E. C. (2006). No curriculum left behind: the effects of the no child left behind legislation on career and technical education. Career and Technical Education Research, 31(3), 157-174. http://dx.doi.org/10.5328/CTER31.3.157

Fuller, B. (2007). Standardizing childhood: The political and cultural struggle over early education. California: Stanford University Press.

Gammage, P. (2006). Early childhood education and care: politics, policies, and possibilities. Early Years: An International Journal of Research and Development, 26(3), 235-248. http://dx.doi.org/10.1080/09575140600898407

Gensler, R. (2006). Effects on no child left behind act of special education regarding standardized testing. Law and Disorder, 1, 10-15.

Goldstein, L. (2008). Preparing preservice teachers for success in nclb’s kindergartens: Learning from experienced teachers' strategies for managing professional relationships with colleagues and parents. Journal of Early Childhood Teacher Education, 29(3), 222-236. http://dx.doi.org/10.1080/10901020802275278

International Reading Association. (2005). Mixed reactions to NCLB. Retrieved February 8, 2006, from http://www.reading .org/publications/reading_today/samples/RTY-0502- survey.html

Karp, S. (2004). The no child left behind test. Rethinking Schools, 19(1), 6-9.

Meier, D., \& Wood, G. (Eds.). (2004). Many children left behind: How the no child left behind act is damaging our children and our schools. Boston: Beacon Press.

Popham, W. J. (2004). America's failing schools: How parents and teachers can cope with nclb. New York: Famler.

Sadovnik, A. R., O'Day, J. A., Bohrnstedt, G. W., \& Borman, K. M. (2007). No child left behind and the reduction of the achievement gap: Sociological perspectives on federal education policy. New York: Routledge.

Shealey, M. W. (2006). The promises and perils of scientifically based research for urban schools. Urban Education, 41(1), 5-19. http://dx.doi.org/10.1177/0042085905282250

Stipek, D. (2006). No child left behind comes to preschool. The Elementary School Journal, 106(5), $455-466$. http://dx.doi.org/10.1086/505440

Sunderman, G. L., Tracey, C.A., Kim, J., \& Orfield, G. (2004). Listening to teachers: classroom realities and no child left behind. Cambrige, MA: The Civil Rights Project at Harvard University.

Sunderman, G. L., James, K. S., \& Orfield, G. (Eds.). (2005). Nclb meets school realities: Lessons from the field. CA: Corwin Press.

Wood, G. (2004). A view from the field: Nclb effects on classrooms and schools. In D. Meier \& G. Wood (Eds.), Many children left behind: how the no child left behind Act is damaging our children and our schools (pp. 33-50). Boston: Beacon Press. 